\title{
Hand Human Recognition Berdasarkan Geometri Telapak Tangan Menggunakan Principal Component Analysis
}

\author{
${ }^{1}$ Nurul Fadillah, ${ }^{2}$ Imanuddin, ${ }^{3}$ Dewi Lestari \\ ${ }^{2}$ imannuddin2096@gmail.com
}

\author{
Program Studi Teknik Informatika, Universitas Samudra, Meurandeh-Langsa 24416, Aceh
}

\begin{abstract}
Self-recognition system is a system that can be used to recognize someone's identity that can be done automatically using a computer. Automatic self-recognition can be done by using body parts or human behavior is known as biometrics. Biometrics is a self-recognition technology that uses body parts or behavior from humans. There are several ways for general biometrics that are often used for self-recognition, such as fingerprints, iris, face, face, voice, signature, hand geometry, and palmprint. Hand geometry is one of the biometrics owned by humans that can describe the geometric structure of a person's hand. The system contained in this study is a palm recognition system that uses feature-based extraction based on Principal Component Analysis (PCA). This technique involves taking the main components of the palm database. To find out the accuracy of the palm recognition system designed in this study, a system trial has been carried out using 21 palm image images from the database. From the results of this test, the results of the system are $52.38 \%$ correctly recognizing input images.
\end{abstract}

Intisari -- Sistem pengenalan diri merupakan sebuah sistem yang dapat digunakan untuk mengenali identitas sesorang yang dapat dilakukan secara otomatis menggunakan komputer. Pengenalan diri secara otomatis dapat dilakukan dengan menggunakna bagian tubuh atau perilaku manusia yang dikenal dengan istilah biometrika. Biometrika merupakan teknologi pengenalan diri yang menggunakan bagian tubuh atau perilaku dari manusia Terdapat beberapa cara untuk biometrika umum yang sering dipakai untuk pengenalan diri, seperti sidik jari (fingerprint), selaput pelangi, (iris), wajah (face), suara (voice), tanda tangan (signature), geometri tangan (hand geometry) dan telapak tangan (palmprint). Geometri tangan merupakan salah satu biometrika yang dimiliki oleh manusia yang dapat menggambarkan struktur geometri tangan seseorang. Sistem yang terdapat dalam penelitian ini adalah sebuah sistem pengenalan telapak tangan yang menggunakan ekstraksi fitur berbasis berbasis Principal Component Analysis (PCA). Teknik ini melibatkan pengambilan komponen utama dari database telapak tangan.
Untuk mengetahui keakuratan sistem pengenalan telapak tangan yang dirancang pada penelitian ini, telah dilakukan uji coba sistem dengan menggunakan input sebanyak 21 citra telapak tangan dari database. Dari hasil pengujian ini, didapatkan hasil performasi sistem adalah 52,38\% dalam mengenali citra input dengan benar.

\section{Kata Kunci : PCA, Telapak Tangan, Biometrika}

\section{PENDAHULUAN}

Sistem pengenalan diri merupakan sebuah sistem yang dapat digunakan untuk mengenali identitas seseorang yang dapat dilakukan secara otomatis menggunakan komputer [1]. Sistem pengenalan diri pada umumnya telah banyak menggunakan kata sandi (password), ID card, atau PIN untuk mengenali identitas seseorang [2].

Permasalahan yang sering muncul yaitu, pengenalan diri dengan sistem tersebut memiliki beberapa kelemahan diantaranya, penggunaan PIN maupun password memiliki kelemahan bahwa seseorang kerap kali lupa akan password yang mereka miliki dan beberapa password dapat dengan mudah di perkirakan oleh orang-orang yang tidak bertanggung jawab [3]. Oleh karena itu dengan adanya biometrika sangat membantu dalam menyelesaikan permasalahan-permasalahan yang muncul dalam sistem pengenalan diri [1][2][3].

Sistem pengenalan diri secara otomatis sangat di butuhkan di era informasi seperti sekarang ini [1]. Pengenalan diri secara otomatis dapat dilakukan dengan menggunakan bagian tubuh atau perilaku manusia yang dikenal dengan istilah biometrika [4][5][6]. Biometrika merupakan teknologi pengenalan diri yang menggunakan bagian tubuh atau perilaku dari manusia [4]. Biometrika memiliki ciri kerja dengan mengukur karakteristik pembeda pada badan atau perilaku seseorang tersebut dengan membandingkan karakteristik yang sebelumnya telah disimpan pada suatu database [7]. Terdapat beberapa cara untuk biometrika umum yang sering dipakai untuk pengenalan diri, seperti sidik jari (fingerprint), selaput pelangi, (iris), wajah (face), suara (voice), tanda tangan (signature), geometri tangan (hand geometry) dan telapak tangan (palmprint) [8]. 
Telapak tangan (palmprint) merupakan salah satu bagian tubuh dari manusia yang memiliki nilai biometrika sehingga relatif baru untuk diteliti dan digunakan dalam sistem pengenalan [9]. Dari permukaan telapak tangan yang dimiliki oleh setiap orang diharapkan dapat menghasilkan ciri yang mampu membedakan masing-masing pemilik telapak tangan yang di identifikasi [10].

Penggunaan telapak tangan dalam proses pengenalan diri sangat banyak digunakan karena telapak tangan memiliki karakteristik yang unik, tidak mudah di palsukan dan cenderung stabil [9][10]. Dengan adanya karakteristik tersebut maka telapak tangan dapat digunakan sebagai alat verifikasi identitas seseorang dengan melakukan pencocokan data yang terdapat dalam sebuah database dengan data yang sudah di masukkan.

\section{METODE PENELITIAN}

\section{A. Tahapan Penelitian}

Beberapa tahapan penelitian yang dilakukan di tunjukkan pada Gambar 1.

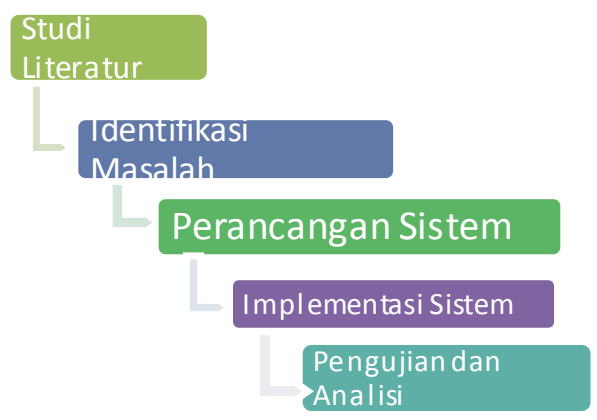

Gambar 1 : Tahapan penelitian

\section{B. Perancangan Sistem}

Pada tahap ini memberikan gambaran yang jelas mengenai bagaimana suatu sistem di konsep dan menghasikan rancang bangun yang lengkap,yang dapat memenuhi kebutuhan pemakai sistem. Sistem pengenalan telapak tangan secara umum terdiri dari :

1. Proses akuisisi citra

2. Preprocessing

3. Ekstraksi fitur (feature extraction)

4. Klasifikasi (classification)

Tujuan dari sistem pengenalan jenis telapak tangan yaitu untuk memudahakn dalam mengenali telapak tangan dengan baik. Perancangan sistem pengenalan telapak tangan dapat dilihat pada gambar 2:

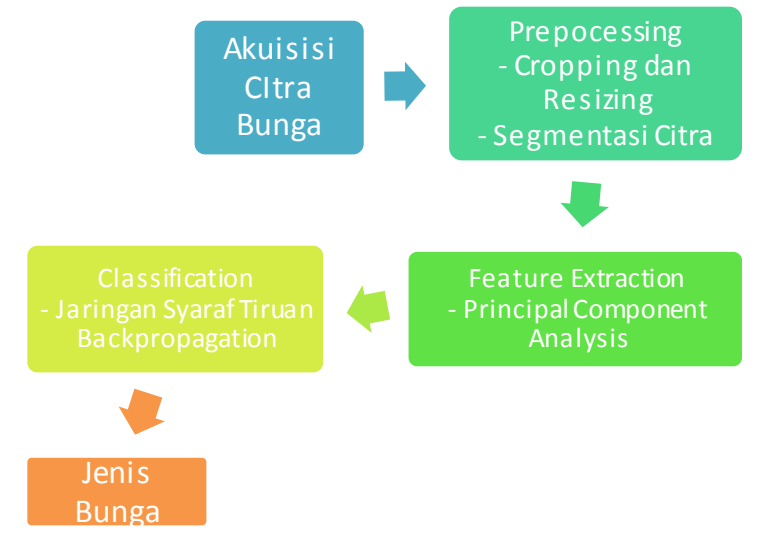

Gambar 2 : Block Diagram

\section{Akuisisi Citra}

Akuisisi citra merupakan proses pengambilan dan pengumpulan data citra yang di perlukan. Baik dengan cara melalui capture maupun scan (Suryani and Candra, 2018). Akuisisi citra pada penelitian dilakukan dengan menggunakan kamera Hand Phone yang memiliki resolusi $12 \mathrm{MP}$. Sampel telapak tangan yang digunakan sebagai objek dalam penelitian ini terdiri atas 5 (lima) telapak tangan. Dari beberapa sampel telapak tangan yang diambil,kemudian di capture dengan warna background yang sama yaitu background berwarna hitam. Telapak tangan yang digunakan sebagai objek dalam penelitian dapat dilihat pada Tabel 1 .

Tabel 1 Telapal tangan yang digunakan sebagai objek dalam penelitian

\begin{tabular}{|c|c|}
\hline \multicolumn{2}{|c|}{ Objek Telapak Tangan } \\
\hline Tangan Dara Havis a & Tangan Nadia Mayanti \\
\hline Tangan Dewi & \\
\hline Tangan Eka & \\
\hline Tangan Pani
\end{tabular}




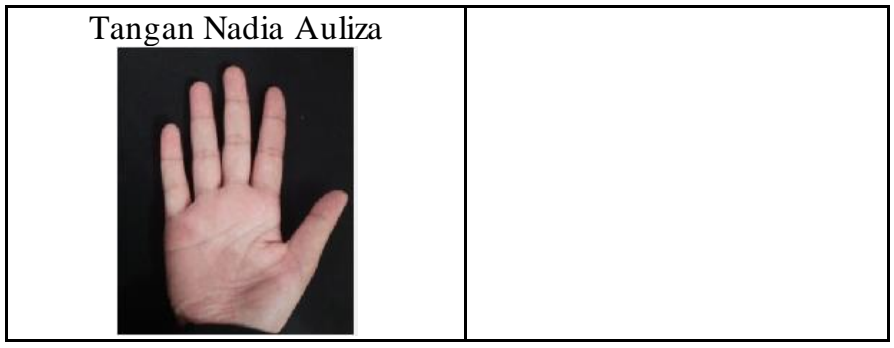

\section{Preprocessing}

Prepocessing merupakan suatu proses pengolahan citra yang dilakukan sebelum proses pengenalan pola (Suryani and Candra, 2018). Prepocessing yang dilakukan dalam penelitian ini yaitu cropping, resizing, dan segmentasi citra.

Berikut beberapa proses yang dilakukan pada tahap penelitian :

1. Cropping dan Resizing

Cropping merupakan proses pengolahan citra yang di lakukan dengan dengan cara memotong suatu citra yang berfungsi untuk mengambil bagian penting dari citra tersebut (Suryani and Candra, 2018). Sedangkan Resizing merupakan proses pengolahan citra yang dilakukan untuk mengubah ukuran citra. Pada penelitian ini, citra tangan dicrop sesuai dengan objek telapak tangan.

2. Segmentasi Citra

Segmentasi Citra merupakan tahapan penting dalam proses pengenalan pola yang bertujuan untuk memisahkan antara objek (foreground) dengan (background) (Suryani and Candra, 2018). Pada penelitian ini, segmentasi citra bunga dilakukan dengan menggunakan metode segmentasi citra dalam color space RGB.

\section{E. Ekstraksi Fitur}

Ekstraksi fitur merupakan proses untuk mengambil ciri atau informasi dari suatu objek dalam citra. Sedangkan fitur merupakan karakteristik unik dari suatu objek (Suryani and Candra, 2018). Dalam penelitian ini, ekstraksi fitur telapak tangan dilakukan dengan menggunakan metode PCA (Principal Component Analysis). Secara umum, tahapan proses ekstraksi fitur telapak tangan yang dilakukan yaitu:

1. Mengkonversi citra telapak tangan RGB ke grayscale (citra 2D).

2. Mengimplementasikan algoritma PCA.

3. Menentukan banyak nilai PC yang akan digunakan sebagai variabel input dalam klasifikasi JST (Jaringan Syaraf Tiruan).

\section{F. Klasifikasi}

Klasifikasi merupakan proses pengelompokkan objek ke dalam kelas yang sesuai. Dalam penelitian ini, proses klasifikasi di lakukan untuk mengelompokkan telapak tangan berdasarkan fitur bentuk telapak tangan dengan menggunakan Metode Jaringan Syaraf Tiruan Backpropagation. Proses klasifikasi pada sistem perancangan ini terdiri dari 2 tahap, yaitu tahap pelatihan dan tahap pengujian.

Berikut proses klasifikasi pada tahap pelatihan :
1. Menentukan variabel data input dan target pelatihan,

2. Menentukan jumlah hidden layer dan jumlah neuron pada hidden layer

3. Membangun arsitektur jaringan

4. Menentukan nilai parameter JST yang mempengaruhi proses pelatihan

5. Melakukan pelatihan jaringan

6. Menghitung akurasi dan nilai MSE

Berikut proses klasifikasi pada fase pengujian :

1. Menentukan variabel data input

2. Memanggil jaringan yang telah dibangun pada proses pelatihan

3. Melakukan pengujian dan menghasilkan output

4. Menghitung nilai akurasi sistem pengenalan jenis bunga.

\section{HASIL DAN PEMBAHASAN}

\section{A. Implementasi Sistem}

Pada tahapan implementasi sistem dilakukan untuk menyelesaikan hasil perancangan sistem agar siap untuk di operasikan. Proses pengenalan jenis bunga terdiri dari dua tahap, yaitu tahap pelatihan dan tahap pengenalan. Berikut pada gambar 3 dan 4 merupakan tampilan halaman pelatihan dan pengujian.

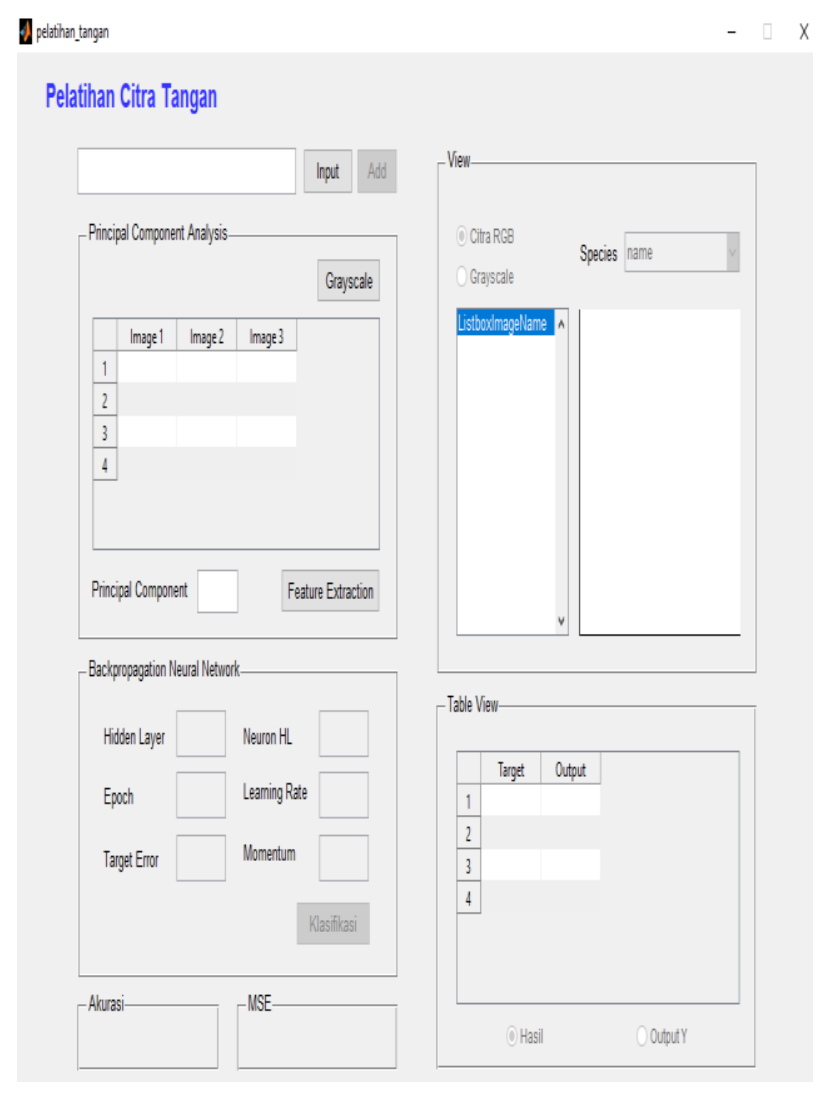

Gambar 3 : Tampilan halaman pelatihan citra tangan 


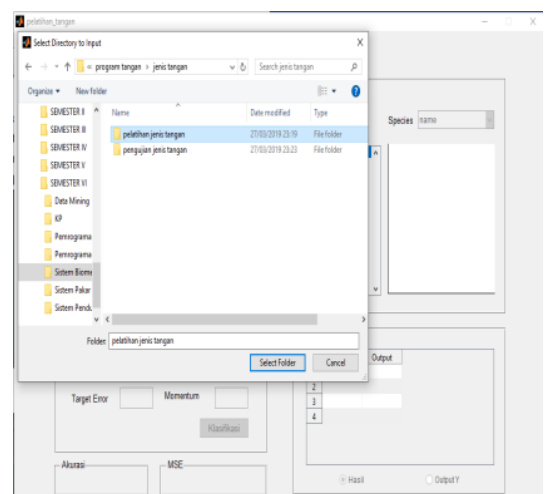

Gambar 4: Tampilan input pelatihan jenis tangan

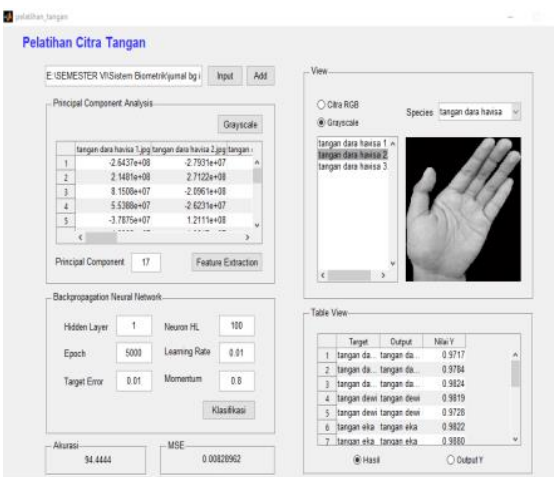

Gambar 5 : Tampilan proses klasifikasi

Pada proses klasifikasi, setelah menginputkan folder pelatihan jenis tangan, kemudian menekan grayscale untuk menyimpan data di citra latih. Kemudian menekan feature Extration untuk mengisikan nilai hidden layer, epoch, target error, neuron HL, Learning Rate, dan momentum. Kemudian menekan kpasifikasi untuk mendapatkan nilai akurasi dan MSE.

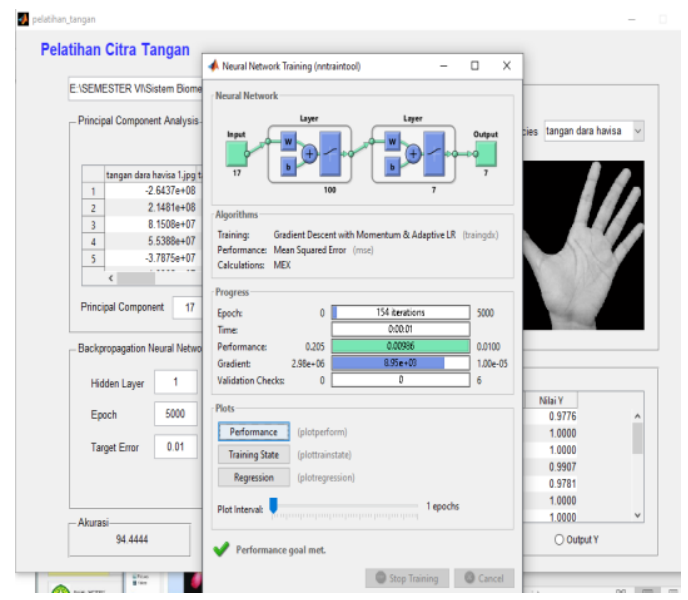

Gambar 6: Tampilan proses mencari nilai Akurasi dan MSE

Setelah tahapan proses pelatihan selesai, selanjutnya masuk pada tahap pengenalan citra telapak tangan.

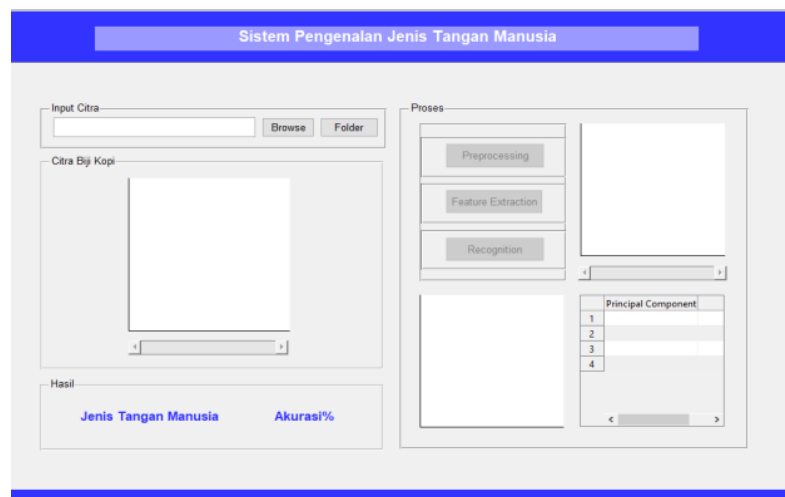

Gambar 7 : Tampilan halaman pengenalan citra tangan

Proses pengenalan suatu citra telapak tangan dapat dilihat pada gambar yang dimulai dari Gambar 8 sampai pada Gambar 15, dan pada Gambar 14 akan ditampilkan ketika user mengklik pemilik telapak tangan dari hasil pengenalan.

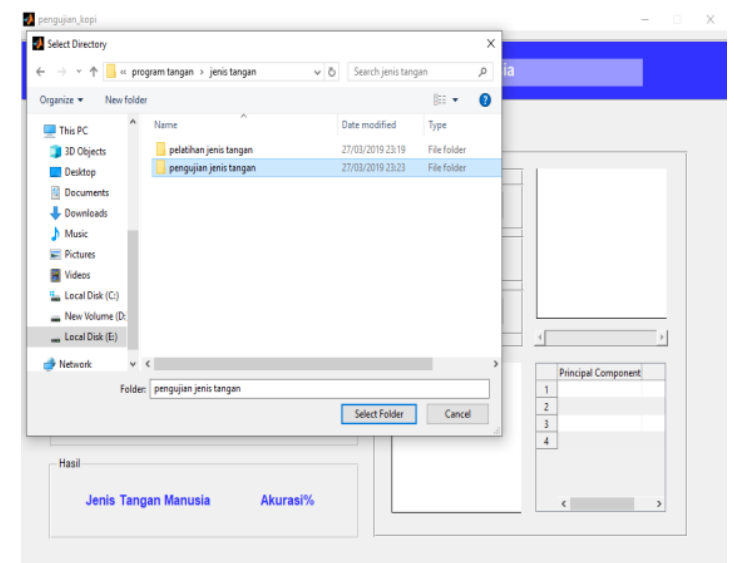

Gambar 8 : Proses input citra uji

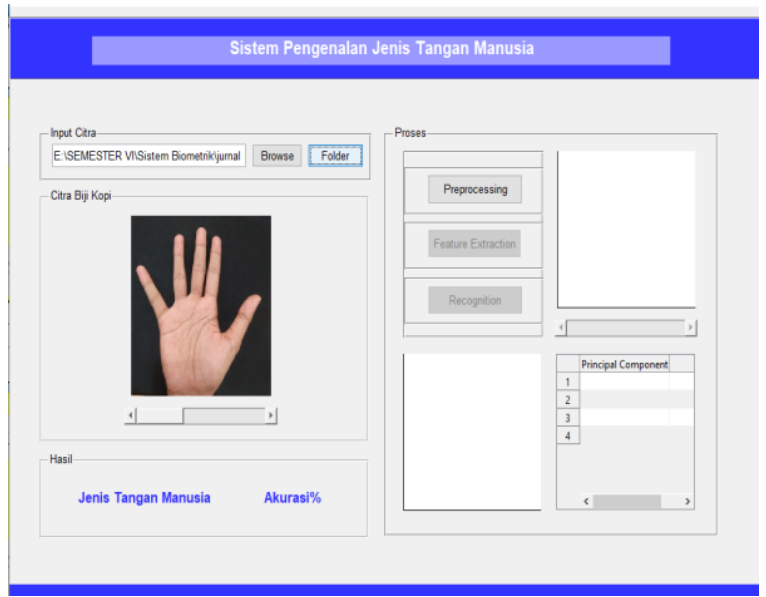

Gambar 9 : Tampilan citra telapak tangan yang di input-kan pada halaman pengenalan 


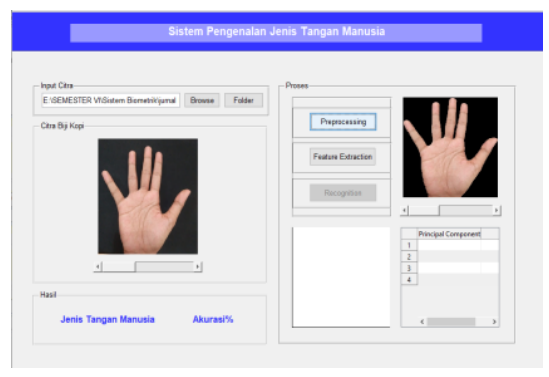

Gambar 10 : Tampilan citra telapak tangan hasil preprocessing pada halaman pengenalan

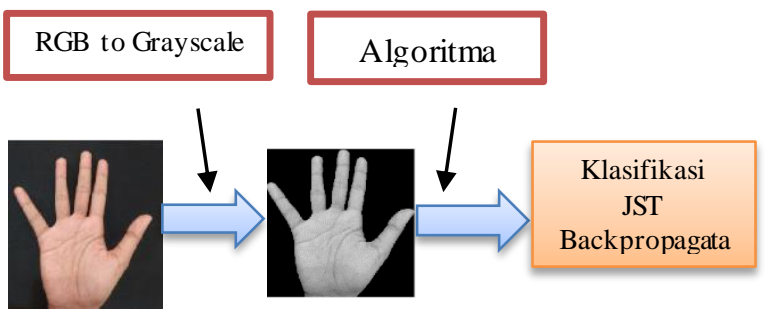

Gambar 11 : Proses tahapan ekstraksi fitur

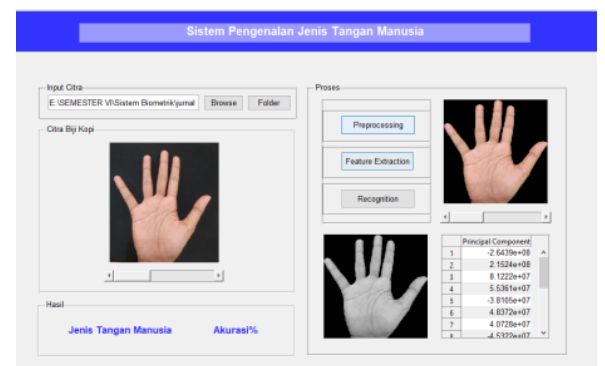

Gambar 12 : Tampilan halaman pengenalan setelah dilakukan proses ekstraksi fitur
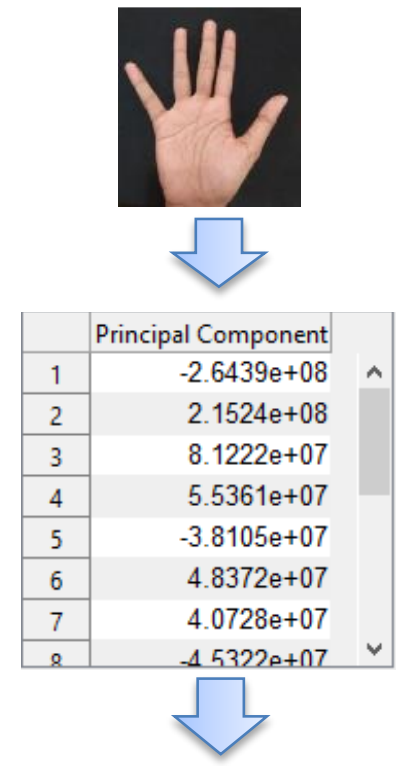

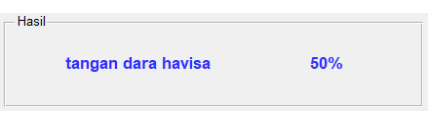

Gambar 13 : Proses Klasifikasi

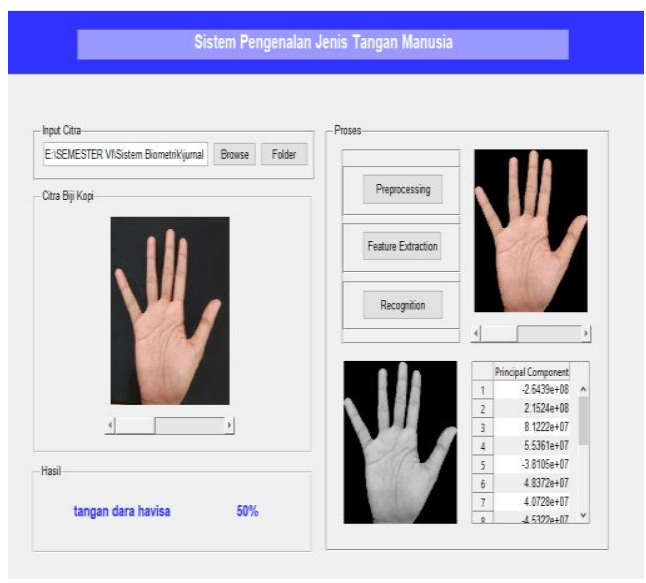

Gambar 14 : Tampilan hasil proses klasifikasi pada halaman pengenalan telapak tangan

\section{B. Pengujian dan Analisis}

Pada tahap pengujian dan analisis dilakukan untuk mencari tahu nilai parameter dan arsitektur jaringan yang optimal untuk sistem, sehingga dapat mengenali pemilik telapak tangan dengan baik.

Pengujian yang dilakukan pada sistem pengenalan telapak tangan menggunakan data citra telapak tangan sebanyak 34 buah citra yang terdiri dari 7 citra telapak tangan untuk di latih dan 7 citra telapak tangan untuk diuji. Data citra latih dari setiap pengenalan telapak tangan ada 18 buah citra, sedangkan data citra uji dari setiap pengenalan telapak tangan ada 21 buah citra.

Setiap citra telapak tangan yang di proses dengan algoritma dengan algoritma PCA akan menghasilkan 100 nilai PC atau vektor karakteristik dari citra telapak tangan. Banyaknya nilai PC yang dihasilkan bergantung pada jumlah citra latih yang digunakan dan nilai ambang batas yang ditentukan. Nilai PC dari citra telapak tangan akan digunakan sebgai variabel input dalam proses klasifikasi JST. Pada pengujian yang dilakukan oleh semua nilai PC (sebanyak 100) akan digunakan sebagai variabel input dalam proses klasifikasi JST sehingga jaringan memiliki jumlah neuron dalam lapisan input sebanyak 100 buah neuron. Proses klasifikasi JST terdiri dari tujuh target pengelompokkan (tangan Dara Havisa, tangan Dewi, tangan Eka, tangan Nadia Auliza, tangan Nadia Mayanti, tangan Pani, tangan rica) sehingga jumlah neuron yang digunakan dalam lapisan output jaringan adalah sebanyak 8 buah neuron.

Tabel 2 menunjukkan hasil klasifikasi pada data citra latih dengan variasi jumlah lapisan tersembunyi dan jumlah neuron dalam lapisan tersembunyi. Pengujian ini dilakukan dengan menggunakan nilai learning rate $=0.001$, momentum $=0.95$, target error $=0.01$, dan epouch $=5000$, yang dilakukan untuk 
mencari jumlah lapisan tersembunyi dan jumlah neuron dalam lapisan tersembunyi yang optimal untuk sistem pengenalan telapak tangan ini.

Tabel 2 Hasil pelatihan dengan variasi jumlah lapisan tersembunyi dan jumlah neuron dalam lapisan tersembunyi

\begin{tabular}{|c|c|l|}
\hline $\begin{array}{c}\text { Jumlah neuron } \\
\text { dalam hidden layer }\end{array}$ & $\begin{array}{c}\text { Hidden } \\
\text { layer }\end{array}$ & Akurasi (\%) \\
\hline \multirow{2}{*}{70} & 1 & $100 \%$ \\
\cline { 2 - 3 } & 2 & $83,3333 \%$ \\
\hline \multirow{3}{*}{75} & 1 & $77.778 \%$ \\
\cline { 2 - 3 } & 2 & $88,8889 \%$ \\
\cline { 2 - 3 } & 3 & $94,4444 \%$ \\
\hline \multirow{2}{*}{80} & 1 & $100 \%$ \\
\hline \multirow{3}{*}{85} & 2 & $94,4444 \%$ \\
\cline { 2 - 3 } & 1 & $66.667 \%$ \\
\cline { 2 - 3 } & 2 & $94,4444 \%$ \\
\hline \multirow{3}{*}{90} & 3 & $94,4444 \%$ \\
\cline { 2 - 3 } & 2 & $94,4444 \%$ \\
\cline { 2 - 3 } & 3 & $88.8889 \%$ \\
\hline \multirow{2}{*}{95} & 1 & $88.8333 \%$ \\
\hline \multirow{2}{*}{100} & 2 & $94,4444 \%$ \\
\cline { 2 - 3 } & 1 & $94,4444 \%$ \\
\cline { 2 - 3 } & 2 & $94,4444 \%$ \\
\hline
\end{tabular}

\begin{tabular}{|l|l|l|l|}
\hline $\begin{array}{c}\text { Momen } \\
\text { tum }\end{array}$ & $\begin{array}{c}\text { Learning } \\
\text { rate }\end{array}$ & \multicolumn{2}{|c|}{ Pengenalan (\%) } \\
\hline & & Citra latih & Citra uji \\
\hline 1 & 70 & 83.3333 & $94 \%$ \\
\hline 1 & 80 & 94,4444 & $100 \%$ \\
\hline
\end{tabular}

Hasil klasifikasi pada citra latih selama pelatihan menunjukkan bahwa akurasi hasil klasifikasi tertinggi yang didapatkan adalah $100 \%$ yang terdapat pada beberapa jaringan lapisan tersembunyi. Masing-masing jumlah neuron dalam lapisan tersembunyi 70 untuk jumlah lapisan tersembunyi $=1$, 80 untuk jumlah lapisan tersembunyi $=1$. Kemudian, untuk menambahkan jumlah lapisan-lapisan tersembunyi dan jumlah neuron dalam lapisan tersembunyi yang optimal dilakukan pengujian pada data citra uji dengan menggunakan jumlah lapisan-lapisan tersembunyi dan jumlah neuron dalam lapisan tersembunyi yang menghasilkan akurasi hasil klasifikasi tertinggi yang di dapatkan dari proses pelatihan sebelumnya, seperti yang di tunjukkan pada Tabel 3 .

Tabel 3 Hasil pengenalan pada data citra latih dan data citra uji untuk mencari arsitektur jaringan yang optimal.

\begin{tabular}{|c|c|c|c|}
\hline $\begin{array}{c}\text { Hidden } \\
\text { layer }\end{array}$ & $\begin{array}{c}\text { Jumlah } \\
\text { neuron dalam } \\
\text { hidden layer }\end{array}$ & \multicolumn{2}{|c|}{ C. Pengenalan (\%) } \\
\hline & & Citra latih & Citra uji \\
\hline 1 & 70 & 83.3333 & $100 \%$ \\
\hline 1 & 80 & 94,4444 & $100 \%$ \\
\hline
\end{tabular}

Tabel 3 menunjukkan bahwa untuk nilai learning rate $=$ 0.001 , momentum $=0.8$, target error $=0.01$, dan epoch $=$ 5000, arsitektur jaringan yang optimal untuk sistem adalah arsitektur jaringan dengan jumlah lapisan tersembunyi $=1$ dan jumlah neuron dalam lapisan tersembunyi $=80$. Selanjutnya untuk mendapatkan nilai momentum dan learning rate yang optimal dapat dilakukan pengujian pada data citra latih dan citra uji, seperti yang di tunjukkan pada Tabel 4.

Tabel 4 Hasil pengenalan pada data citra latih dan data citra uji dengan variasi nilai momentum dan learning rate. Nilai momentum dan learning rate yang didapatkan dari pengujian ini menghasilkan akurasi hasil pengenalan yang tinggi adalah 70 dan 80 dengan menghasilkan akurasi hasil pengenalan pada citra latih sebesar $100 \%$ dan citra uji $94 \%$.

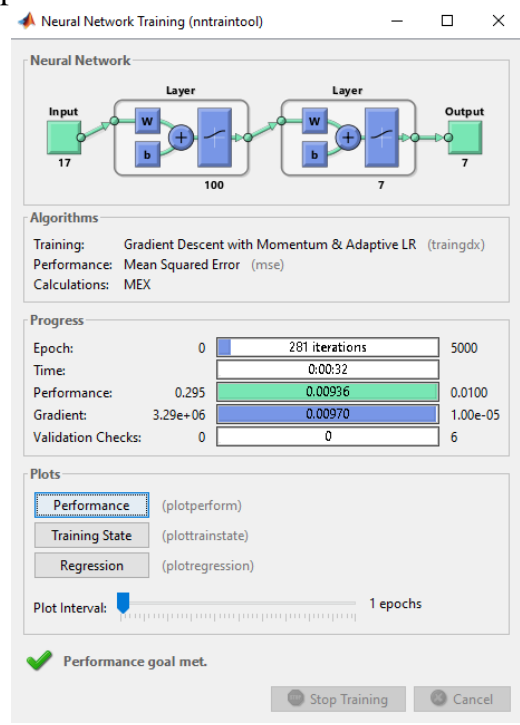

Gambar 15 : Proses pelatihan kinerja jaringan

Proses pelatihan berhenti pada saat kriteria MSE 0,000000 tercapai dengan iterasi dilakukan sebanyak 000 kali dan lama waktu pelatihan 00:00:10 ( detik), dapat dilihat pada Gambar 16. Berdasarkan pengujian yang telah dilakukan, didapatkan nilai parameter dan arsitektur jaringan yang optimal untuk sistem pengenalan telapak tangan ini, yaitu :
a. Jumlah iterasi (epouch) : 5000
b. Target error : 0.01
c. Learning rate : 0.001
d. Momentum : 0.8
e. Jumlah hidden layer : 1
f. Jumlah neuron tersembunyi : 80

Dari nilai parameter dan arsitektur jaringan optimal yang di dapatkan, dilakukan pengujian pada data citra uji yang dapat dilihat pada gambar 16. 


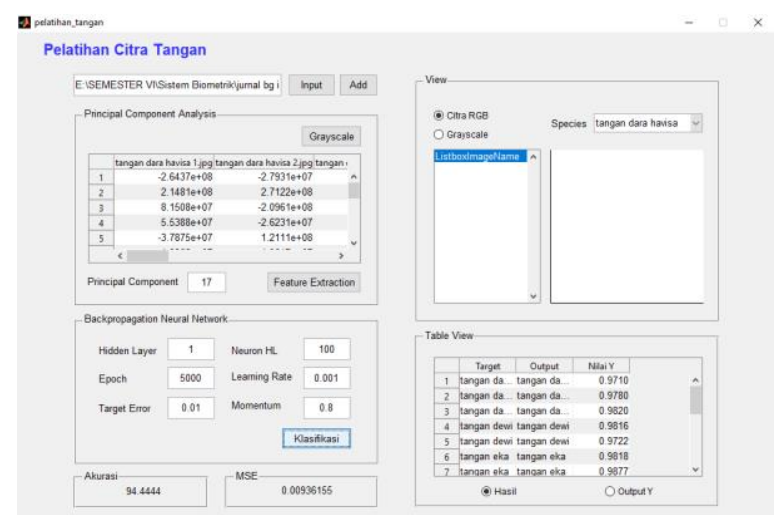

Gambar 16 : Tampilan proses pengenalan data citra uji Hasil pengenalan data citra uji dapat dilihat pada Tabel 5.

Tabel 5 Hasil pengenalan data citra uji

\begin{tabular}{|c|c|c|c|c|}
\hline \multirow{2}{*}{$\begin{array}{l}\text { Pemilik } \\
\text { telapak } \\
\text { tangan }\end{array}$} & \multicolumn{3}{|c|}{ Pengujian } & \multirow[b]{2}{*}{ Akurasi (\%) } \\
\hline & Benar & Salah & Jumlah & \\
\hline Dara Havisa & 1 & 2 & 3 & $33.3333 \%$ \\
\hline Dewi & 3 & 0 & 3 & $100 \%$ \\
\hline Eka & 3 & 0 & 3 & $100 \%$ \\
\hline Nadia Auliza & 2 & 1 & 3 & $66.6667 \%$ \\
\hline $\begin{array}{l}\text { Nadia } \\
\text { Mayanti }\end{array}$ & 2 & 1 & 2 & $66.6667 \%$ \\
\hline Rica & 0 & 3 & 3 & $0 \%$ \\
\hline Pani & 0 & 3 & 3 & $0 \%$ \\
\hline \multicolumn{4}{|c|}{ Rata-rata } & $52,38 \%$ \\
\hline
\end{tabular}

Sistem pengenalan telapak tangan yang menggunakan metode PCA dan JST Backpropagation ini dapat mengenali pemilik telapak tangan dengan rata-rata akurasi hasil pengenalan $52,38 \%$.

\section{KESIMPULAN DAN SARAN}

Dari hasil penelitian dan pembahasan sebelumnya dapat disimpulkan bahwa metode Principal Component Analysis Jaringan Syaraf Tiruan Backpropagation menunjukkan kinerja yang baik dalam sistem pengenalan telapak tangan. Nilai parameter dan arsitektur Jaringan Syaraf Tiruan yang optimal untuk sistem pengenalan telapak tangan ini adalah: jumlah iterasi (epouch) : 5000, target error : 0.01, learning rate : 0.001, momentum : 0.8, jumlah hidden layer : 1 , jumlah neuron tersembunyi : 80. Rata-rata akurasi hasil pengenalan telapak tangan dari sistem pengenalan telapak tangan ini adalah sebesar $52.38 \%$.

Penelitian mengenai pengenalan jenis bunga menggunakan Principal Component Analysis dan Jaringan Syaraf Tiruan ini masih banyak kekurangan dan keterbatasan. Penulis memiliki beberapa saran untuk pengembangan penelitian pengenalan telapak tangan selanjutnya, yaitu : Menambahkan pemilik telapak tangan yang lain selain 7 telapak tangan yang digunakan dalam penelitian ini. Menggunakan metode segmentasi citra yang lebih kompleks dan lebih menarik, agar citra telapak tangan dapat diambil dengan latar belakang (background) bebas. Pengambilan citra telapak tangan dapat dilakukan secara langsung dengan menggunakan sebuah kamera.

\section{DAFTAR PUSTAKA}

[1] D. Setiawan, I. Arifin, and R. Ardianto, "Implementasi Pengembangan Sistem Media Pembelajaran Pengenalan Komputer: Program Studi Sistem Informasi Universitas PGRI Madiun," Intensif, vol. 2, no. 2, pp. 127-135, 2018.

[2] F. Ilmu, U. Sains, J. Raya, and S. Padang, "Sistem informasi pembelajaran identifikasi dan pengenalan dini bahasa suku sentani berbasis kearifan lokal," vol. 2, no. 12, pp. 9-16, 2018.

[3] T. Moloharto, S. Al Faraby, and K. M. Lhaksmana, "Implementasi Alignment Point Pattern Pada Sistem Pengenalan Sidik Jari Menggunakan Sidik Jari Menggunakan Template Matching," e-Proceeding Eng., vol. 6, no. 1, pp. 2442-2450, 2019.

[4] S. Emerich and B. Belean, "Biometrics Recognition based on Image Local Features Ordinal Encoding," Int. J. Adv. Comput. Sci. Appl., vol. 8, no. 12, 2018.

[5] A. Y. Rahman, S. Sumpeno, and M. H. Purnomo, "Video minor stroke extraction using learning vector quantization," 2017 th Int. Conf. Inf. Commun. Technol. ICoIC7 2017, no. July 2018, 2017.

[6] A. Y. Rahman and S. Sumpeno, "Segmentasi Arca pada Museum Mpu Tantular Sidoarjo Menggunakan Learning Vector Quantization," no. December, pp. 16-21, 2016.

[7] M. Stanuch and A. Skalski, "Artificial database expansion based on hand position variability for palm vein biometric system," IST 2018 - IEEE Int. Conf. Imaging Syst. Tech. Proc., pp. 1-6, 2018.

[8] C. Ching Ho, M. Ali Hussin, and H. Ng, "Match score fusion of fingerprint and face biometrics for verification," vol. 77, no. 18, pp. 93-102, 2015.

[9] M. N. Osman, K. A. Sedek, M. Maghribi, and N. Hidayah, "ANotify : A Fingerprint Biometric-Based and Attendance Web-Based Management System with SMS Notification for Industrial Sector," vol. 3, no. 1, pp. 3645, 2018.

[10] A. Aglio-Caballero, B. Rios-Sanchez, C. Sanchez-Avila, and M. J. M. De Giles, "Analys is of local binary patterns and uniform local binary patterns for palm vein biometric recognition," vol. 2017-Octob, pp. 1-6, 2017. 
